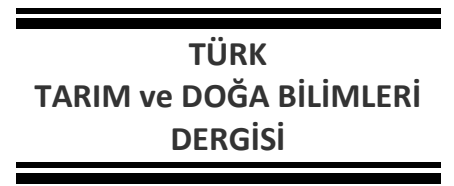

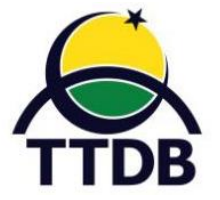

www.dergipark.gov.tr/turkjans Araştırma Makalesi
TURKISH

JOURNAL Of AGRICULTURAL and NATURAL SCIENCES

\section{Tavuk Nugget Formülasyonlarında Buğday Unu Yerine Bal Kabağı Tozu Kullanımı Üzerine Bir Araştırma}

\author{
Burcu ÖZTÜRK-KERIMOĞLU*, Meltem SERDAROĞLU \\ Ege Üniversitesi Mühendislik Fakültesi Gıda Mühendisliği Bölümü 35100 Bornova, İzmir \\ *Sorumlu yazar: burcu.ozturk@ege.edu.tr \\ Geliş Tarihi: 04.11.2019 Düzeltme Geliş Tarihi: 10.05.2020 Kabul Tarihi: 21.05.2020
}

\title{
Öz
}

Et ürünlerinin diyet lifi kaynağı bileşenler ile yeniden formüle edilmesi, günümüzde giderek artan sağlıklı et ürünlerinin geliştirilmesi talebini karşılayacak önemli bir yaklaşımdır. Mevcut çalışmada, tavuk nugget üretiminde sıvı kaplama formülasyonlarında buğday unu yerine farklı oranlarda bal kabağı tozu (BKT) kullanımının kimyasal, teknolojik ve duyusal kalite kriterlerine etkilerinin araştırılması amaçlanmıştır. Bu doğrultuda, \%100 buğday unu (K), \%50 buğday unu + \%50 BKT (BK) ve \%100 BKT (B) içeren sıvı kaplamalar kullanılarak tavuk nugget üretimi gerçekleştirilmiştir. Sıvı kaplamada BKT kullanımı örneklerin nem, yağ ve karbonhidrat miktarları ile enerji değerlerini değiştirmezken protein miktarını önemli düzeyde arttırmıştır. Sıvı kaplamaların konsistens değerlerinin birbirine yakın olduğu kaydedilmiştir. Kaplama formülasyonlarına BKT ilavesi, kaplama tutunma oranını yükselterek ürünlerin teknolojik kalitesinin gelişimini sağlamıştır. BK ve B örneklerinde pişirme verimi ve yağ emilim miktarı ise buğday unu ile hazırlanan K örneklerine eşdeğer bulunmuştur. Sıvı kaplamalarda BKT kullanımı ve artan BKT konsantrasyonu, nugget örneklerinde aydınlık ve sarılık değerlerini önemli derecede düşürmüştür. Duyusal değerlendirmede, sıvı kaplamada BKT kullanımının ürünlerde görünüm ve renk beğenisini olumsuz yönde etkilediği, ancak doku ve lezzet gibi diğer duyusal kalite parametrelerinin ve genel kabulün standart ürünlere eşdeğer olduğu tespit edilmiştir. Sonuç olarak, kaplamalı et ürünlerinin sIVı kaplama formülasyonlarında kurutulmuş bal kabağı ve türevlerinin buğday unu ikamesi olarak kullanımı neticesinde teknolojik kalite ve besleyici değerin yükseltilerek duyusal açıdan standart ürünlere benzer genel kabul edilebilirliğe sahip ürünlerin elde edilebileceği bulgulanmıştır.

Anahtar Kelimeler: Bal kabağı, buğday, kaplamalı et ürünü, sıvı kaplama, tavuk nugget

A Study on the Use of Pumpkin Powder Instead of Wheat Flour in Chicken Nugget Formulations

\begin{abstract}
The reformulation of meat products with dietary fiber sources is an important approach to meet today's growing demand for healthier meat products. In the present study, it was aimed to investigate the incorporation of different amounts of pumpkin powder (PP) instead of wheat flour on chemical, technological and sensory quality in batter formulations of chicken nuggets. Nugget production was carried out by using batters containing $100 \%$ wheat flour (K), 50\% wheat flour $+50 \%$ PP (BK) and $100 \%$ PP (B). The use of PP in batter did not change the moisture, fat, and carbohydrate contents as well as energy values, but it increased the protein content significantly. It was recorded that the consistency of the batters was similar to each other. Addition of PP increased the batter pick up and improved the technological quality. BK and B samples had similar cooking yield and oil absorption ratio to $\mathrm{K}$ samples prepared with wheat flour. The use of PP and its increasing levels led to significant decrease in luminosity and yellowness of the nuggets. Incorporation of PP negatively affected the sensory appearance and color scores, however rest of the sensory parameters such as texture and flavor as well as general acceptability were similar to that of standard products. Consequently, it was concluded that the use of dried pumpkin and its derivatives as wheat flour substitutes in batter formulations of coated meat products could improve technological quality and nutritive value and it could be possible to obtain products that have equivalent overall impression to standard ones in terms of sensory quality.
\end{abstract}

Key Words: Pumpkin, wheat, coated meat product, batter, chicken nugget 
Giriş

Kanatlı eti üretimi ve tüketimi, tüm dünyada olduğu gibi ülkemizde de son yıllarda büyük bir ivme kazanmıştır. Küresel çapta ve Türkiye genelinde yapılan çalışmalarda bu ivmenin gelecekte de yükseleceği öngörülmektedir (BESD-BíR, 2017; TAGEM, 2018; WATT, 2018). Günlük hayatın hızlanması, teknolojideki ilerlemeler, sosyo-ekonomik statünün gelişmesi ve ailede aktif çalışma hayatının içinde olan birey sayısının artışı gibi faktörlerin etkisi ile birlikte, tüketime hazır kanatlı eti ürünlerine olan talep her geçen gün artmaktadır. İşlenmiş tavuk eti ürünlerinin içerisinde önemli bir payı kaplamalı et ürünleri oluşturmaktadır. "Kaplama" terimi; gıdanın içine daldırıldığı su, un, yumurta, nişasta ve baharat gibi bileşenlerden oluşan sıvı karışımlar ile bu sıvı karışımları takiben uygulanan, un, nişasta ve galeta unu gibi bileşenleri içeren kuru karışımları ifade etmektedir (Kaymak-Ertekin, 2005). Genellikle "nugget" olarak adlandırılan kaplamalı tavuk eti ürünlerinin üretiminde; 1. Tavuk eti, tuz ve su ile karıştırılarak (yağ veya tavuk derisi de ilave edilebilir) elde edilen harç kalıplar aracılığıyla porsiyonlanır. 2. Her porsiyonun yüzeyi kuru ve unlu bir bileşen ile muamele edilir (ön unlama). 3. Farklı unlar, nişastalar, sıvı yağ, yumurta, baharatlar, vb. bileşenlerden oluşan yarı-sıvı hamur içerisinde yüzey kaplanır (sıvı kaplama). 4. Un, yağ/un karışımı ve/veya galeta unu vb. kuru bileşenler ile porsiyonlar kaplanarak dış yüzey oluşturulur (dış kaplama). 5. Kaplama işlemleri tamamlanan ürünler son olarak derin yağda kızartılır (Akgün, 2006; Adedeji ve Ngadi, 2011; de Carvalho ve ark., 2018).

Son yıllarda et ürünlerinin sağlık risklerini tetiklemesi gerekçesiyle tüketiciler üzerinde olumsuz izlenime neden olması, et ürünleri formülasyonlarının doğal ve fonksiyonel bileşenler kullanılarak oluşturulması stratejisini ön plana çıkarmıştır (Öztürk ve Serdaroğlu, 2017a, 2017b; Öztürk, 2018). Yüksek oranda rağbet gören kaplamalı tavuk eti ürünlerinde de seçeneklerin çoğaltılması ve sağlıklı beslenme arayışında olan tüketiciler için bu tip ürünlerin yeniden formüle edilmesi oldukça önemli bir yaklaşımdır. Et ürünleri, her ne kadar başta protein olmak üzere besleyici değeri yüksek olan bileşenlerin iyi bir kaynağı olsa da diyet lifi içeriği açısından oldukça yetersizdir (Pathera ve ark., 2017). Bu çerçevede, et ürünleri formülasyonlarında diyet liflerinin kullanımı, ürünlerin besleyici değeri ve toplam kalitesinin yükseltilmesinde önemli bir seçenektir. Diyet lifi, "nişasta olmayan polisakkarit türevi bileşen" olarak tanımlanmaktadır (Harris ve Ferguson, 1999). Amerikan Tahıl Kimyagerleri Birliği (AACC) Diyet Lifi Tanımlama Derneği tarafından yapılan tanıma göre diyet lifi: "Sindirime ve ince bağırsakta emilime dirençli, kalın bağırsakta tamamen veya kısmi olarak fermente edilen, bitki ve analoglarına ait karbonhidratların yenilebilir kısımları" olarak ifade edilmektedir (Bodner ve Sieg, 2009). Et ürünlerinde kullanılan diyet lifleri, ürünlerin sağıık profili ve besin değerini yükseltmenin yanı sıra toplam yağ miktarının azaltılması, su bağlama kapasitesi gibi fonksiyonel parametrelerin iyileştirilmesi, pişirme kaybını ve maliyeti düşürerek ürün veriminin arttırılması, dokusal özelliklerin ve depolama stabilitesinin yükseltilmesi gibi birçok avantajı ile toplam kalitenin geliştirilmesi üzerinde etki göstermektedir (Kim ve Paik, 2012; OlmedillaAlonso ve ark., 2013; Öztürk, 2018). Literatürde et ürünlerinin diyet lifleri ile zenginleştirilmesine yönelik birçok araştırma bulunmasına rağmen kaplamalı tavuk eti ürünlerinde kaplama bileşenleri içerisinde diyet lifi kullanımının ürün kalitesine etkilerinin araştırıldığı çalışmalar oldukça sınırlı sayıdadır.

\section{Bal kabağı (Cucurbita moschata}

Duchesne), Türkiye'nin de mikro gen merkezi olarak aralarında yer aldığı birçok dünya ülkesinde yaygın olarak yetiştirilen, yüksek verimli, kolay gelişen ve ekonomik bir kültür bitkisidir (Azevedo-Meleiro ve RodriguezAmaya, 2007; Babaoğlu ve Türkmen, 2017; Dar ve ark., 2017). Bal kabağı; polisakkaritler ve diyet lifi, protein ve peptitler, terpenoit ve steroller, fenolik bileşikler, karotenoitler (özellikle $\alpha$ - ve $\beta$-karoten), doymamış yağ asitleri, vitamin ve minerallerin önemli bir kaynağı olan sağlıklı bir gıdadır (AzevedoMeleiro ve Rodriguez-Amaya, 2007; Dar ve ark., 2017; Serdaroğlu ve ark., 2018; Ali ve ark., 2019). Antidiyabetik, antihipertansif, antitümör, immünomodülatör, antibakteriyel, antihiperkolesterolemik ve antienflamatuar etkileri ile bal kabağı, tıp alanında gerçekleştirilen çalışmalarda da ilgi odağı olmuştur (Dar ve ark., 2017). Lif kaynağı bir bitki olan bal kabağının diyet lifi kompozisyonu ve liflerin fonksiyonel özellikleri incelendiğinde, gıda bileşeni olarak kullanımının kaliteyi geliştirici etkilerinin olduğu tespit edilmiştir (Fedha, 2008). 
Yukarıda değinilen bilgilerin ışığında tasarlanan bu çalışmada, daha sağlıklı ve diyet lifince zenginleştirilmiş kaplamalı tavuk eti ürün formülasyonlarının geliştirilmesi hedefiyle; sıvı kaplama formülasyonlarında buğday unu yerine farklı oranlarda bal kabağı tozu (BKT) kullanılarak üretilen tavuk nuggetların fiziksel, kimyasal, teknolojik ve duyusal kalitesinin incelenmesi amaçlanmıştır.

\section{Materyal ve Metot Materyal}

Mevcut çalışma, Ege Üniversitesi Gıda Mühendisliği Bölümü Et Pilot Tesisi ve Araştırma Laboratuvarlarında gerçekleştirilmiştir. Tavuk nugget üretiminde kullanılan tavuk göğüs eti (Pectoralis major) (\%75.1 nem, \%21.1 protein, \%2.7 yağ ve \%1.1 kül) Tesco-Kipa A.Ş.'den (İzmir) satın alınarak soğuk zincir ile taşınmıştır. Kaplama formülasyonlarında kullanılan buğday unu, ayçiçek yağı, tuz, toz şeker, sodyum karbonat ve baharatlar İzmir ili yerel piyasasından sağlanmıştır. BKT, kuru ve ince öğütülmüş (0.5 $\mathrm{mm}$ ) formda ve ambalajlı olarak Kurucum Gıda

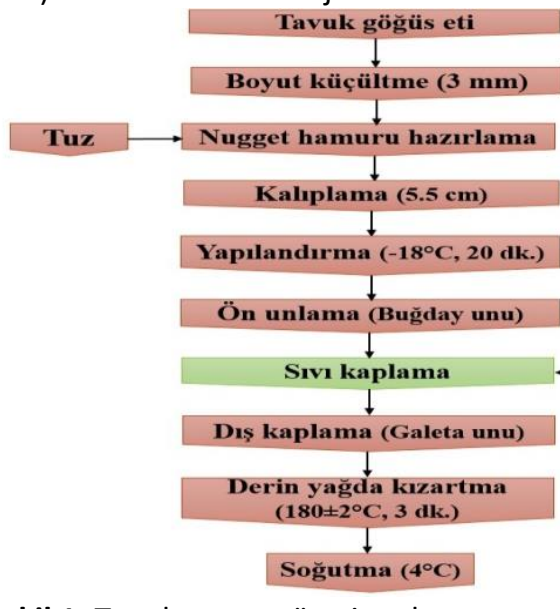

Şekil 1. Tavuk nugget üretim akış şeması

Denemede kullanılan sıvı kaplama

hamuru formülasyonları Çizelge 1'de sunulmaktadır. Buna göre, \%90 un fazı ve \%10 diğer bileşenlerden oluşan kaplama formülasyonlarında un fazları; yalnızca buğday unu (K grubu), 1:1 buğday unu: BKT karışımı (BK grubu) veya yalnızca BKT (B grubu) içerecek şekilde hazırlanmıştır. Sıvı kaplamaların hazırlanması için tüm bileşenler tartılıp karıştırıldıktan sonra üzerlerine ön denemeler ile su kaldırma oranlarına göre belirlenen su miktarları eklenmiş, ardından tüm bileşenlerin su içerisinde homojen şekilde dağılması için blender (Arçelik, Türkiye) kullanılarak $5 \mathrm{dk}$.
A.Ş.'den (Isparta) tedarik edilmiş ve üretimde kullanılmadan önce kuru ve serin ortamda muhafaza edilmiştir. BKT'nin kimyasal kompozisyonunun \%69.09 karbonhidrat, \%9.55 protein, $\% 8.92$ nem, $\% 6.76$ yağ ve $\% 5.68$ külden oluştuğu tespit edilmiştir. Deneme örneklerinin analizinde kullanılan tüm kimyasal maddeler analitik saflıkta satın alınmıştır.

\section{Tavuk Nugget Üretimi}

Çalışma kapsamında üretilen tavuk nugget örneklerinin üretim akış şeması Şekil 1'de sunulmaktadır. Nugget hamurunun hazırlanması amacıyla tavuk göğüs eti, kıyma makinasının (Arnica, Türkiye) $3 \mathrm{~mm}$ 'lik aynasından çekilerek kıyma haline getirilmiş ve tuz (\%1) eklenip karıştırılmıştır. Nugget hamuru, $5.5 \mathrm{~cm}$ çapındaki dairesel kalıplar kullanılarak porsiyonlanmış ve ön unlama işlemi öncesinde $18^{\circ} \mathrm{C}$ 'de $20 \mathrm{dk}$. boyunca dokunun sıkılaşması amacıyla bekletilmiştir. Süre sonunda porsiyonlar buğday unu ile yüzeyleri kaplanarak ön unlama işlemine tabi tutulmuştur. boyunca karıştırma işlemi uygulanmıştır. Ön unlama işlemi tamamlanan örnekler, sıvı kaplama hamurlarının içerisine daldırılarak yüzeyin tamamen kaplanması sağlanmıştır. Ardından örnekler fazla sıvı kaplamanın süzülmesi için 10 sn. boyunca Izgarada bekletilmiştir. Son olarak, dış kuru kaplama olarak kullanılan galeta unu ile muamele edilen örnekler, $180 \pm 2^{\circ} C^{\prime}$ ye ısıtılmış fritözde (Felix, Türkiye) $3 \mathrm{dk}$. boyunca ayçiçek yağı ile derin yağda kızartma işlemine tabi tutulmuştur. Kızartma işlemi tamamlandıktan sonra örnekler $4^{\circ} \mathrm{C}^{\prime}$ ye soğutulmuştur. 
Çizelge 1. Tavuk nugget üretimlerinde kullanılan sıvı kaplama hamuru formülasyonları

\begin{tabular}{|c|c|c|c|c|}
\hline & & \multicolumn{3}{|c|}{ Deneme grupları* } \\
\hline & Bileşen (\%) & K & BK & B \\
\hline \multirow{2}{*}{ 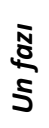 } & Buğday unu & 90.0 & 45.0 & 0.0 \\
\hline & Bal kabağı tozu (BKT) & 0.0 & 45.0 & 90.0 \\
\hline \multirow{8}{*}{ 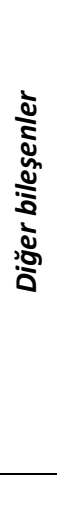 } & $\operatorname{Tuz}(\mathrm{NaCl})$ & 1.0 & 1.0 & 1.0 \\
\hline & Sodyum karbonat $\left(\mathrm{Na}_{2} \mathrm{CO}_{3}\right)$ & 2.0 & 2.0 & 2.0 \\
\hline & Ayçiçek yağı & 2.0 & 2.0 & 2.0 \\
\hline & Şeker & 2.0 & 2.0 & 2.0 \\
\hline & Tatlı kırmızı toz biber & 1.0 & 1.0 & 1.0 \\
\hline & Toz karabiber & 1.0 & 1.0 & 1.0 \\
\hline & Toz kimyon & 1.0 & 1.0 & 1.0 \\
\hline & Kuru bileşenler: su oranı & $1: 1$ & $1: 2.5$ & $1: 3$ \\
\hline
\end{tabular}

* K: Un fazının tamamı buğday unu içeren sıvı kaplamalı deneme grubu, BK: Un fazında buğday unu ve bal kabağı tozu karışımı (1:1) içeren sıvı kaplamalı deneme grubu, B: Un fazının tamamı bal kabağı tozu içeren sıvı kaplamalı deneme grubu

\section{Metot}

\section{Kimyasal Kompozisyon ve Enerji}

Deneme örneklerinin nem miktarı, numunelerin $105^{\circ} \mathrm{C}^{\prime}$ lik etüvde sabit tartım ağırlığına gelinceye kadar suyunun uzaklaştırılması sonucu meydana gelen ağırlık kaybından yüzdesel olarak hesaplanmıştır (AOAC, 2012). Protein miktarı tayini, LECO FP 528 protein/nitrojen analizörü (Leco Ins., UK) kullanılarak Dumas yakma metodu ile gerçekleştirilmiştir. Yağ miktarı, metanolkloroform ekstraksiyonu yöntemi kullanılarak tespit edilmiştir (Flynn ve Bramblett, 1975). Kül miktarı, örneklerin $550^{\circ} \mathrm{C}^{\prime}$ ye ayarlanmış kül fırınında esmer lekeler kalmayıncaya kadar yakılmasıyla meydana gelen ağırlık kaybından yüzdesel olarak hesaplanmıştır (AOAC, 2012). Örneklerin karbonhidrat miktarı kimyasal kompozisyon üzerinden oransal olarak tespit edilmiştir. Enerji değeri (kcal/100 g); $100 \mathrm{~g}$ örnekte yağ (9 kcal $/ \mathrm{g})$, protein $(4.02 \mathrm{kcal} / \mathrm{g})$ ve karbonhidratın $(3.87 \mathrm{kcal} / \mathrm{g})$ verdiği enerji toplamı üzerinden hesaplanmıştır (Mansour ve Khalil, 1997).

\section{Teknolojik Karakterler Konsistens}

Sıvı kaplama hamurlarının akışkanlık derecesi ölçümü, Bostwick Konsistometresi (PCE Instruments, İngiltere) kullanılarak oda sıcaklığında gerçekleştirilmiştir. Su terazisi ayarlanan konsistometre haznesine $50 \mathrm{ml}$ örnek doldurulmuş, yaylı tahliye kapağı açılarak örneğin 30 sn. sonra ulaştığı mesafe cm cinsinden kaydedilmiştir.

\section{Kaplama tutunma oranı}

Tavuk nugget örneği sıvı kaplama öncesi tartılmış, sıvı kaplama hamuruna daldırılmış, çıkarılıp süzülmesi için $10 \mathrm{sn}$. bekletilmiş ve tekrar tartılmıştır. Kaplama tutunma oranı (KTO) aşağıdaki eşitlik yardımıyla hesaplanmıştır (Chen ve ark., 2009):

KTO $(\%)=[($ Kaplanmış örnek ağırlığı - Kaplama öncesi örnek ağırlığı) / Kaplanmış örnek ağırlığı]

$$
x 100
$$

Pişirme verimi

Deneme örneklerinin pişirme verimi, Murphy ve ark. (1975) tarafından belirtilen metoda göre pişirme öncesi ve sonrası ağırlıklar kaydedilerek aşağıdaki eşitlikten hesaplanmıştır:

Pişirme verimi $(\%)=($ Pişmiş örnek ağırlığı $/$ Çiğ örnek ağırlığı) x 100

\section{Yağ emilim miktarı}

Tavuk nugget örneklerinde derin yağda kızartma boyunca emilen yağın miktarı, kızartma öncesi dış kaplama ile kaplanmış çiğ örnekte ve kızartma sonrası son üründe tayin 
edilen yağ miktarları değişimi üzerinden yüzdesel olarak belirlenmiştir (Öztürk, 2018).

\section{Renk}

Nugget örneklerinin dış yüzeyinde portatif renk ölçüm cihazı (Konica Minolta, CR200, Japonya) kullanılarak altı farklı noktadan renk ölçümü yapılmıştır. Ölçüm sonuçları CIA L* (aydınlık), a* (kırmızılık) ve b*(sarılık) olarak ifade edilmiştir.

\section{Duyusal Değerlendirme}

Deneme örneklerine uygulanan duyusal analizler, 9 puanlı hedonik skala (9: Aşırı beğendim, 1: Aşırı beğenmedim) kullanılarak gerçekleştirilmiştir (Stone ve Sidel, 2004). Duyusal değerlendirmede Ege Üniversitesi Gıda Mühendisliği personel ve öğrencilerinden oluşan 20 kişilik gönüllü panelist grubu kullanılmıştır. Panelistlere örnekler standart porsiyonlar halinde, yağsız tavada her iki yüzü eşit sürede ısıtılarak ve tesadüfi kodlar verilerek sunulmuştur. Duyusal değerlendirmede panelistlerin tavuk nugget örneklerini dış görünüş, renk, çıtırlık, yağlılık, sululuk ve genel kabul edilebilirlik özellikleri bakımından puanlamaları istenmiştir.

\section{Istatistiksel Analiz}

Verilerin istatistiksel değerlendirmesi SPSS programı (v 25.0, IBM, ABD) kullanılarak gerçekleştirilmiştir. Deneme kapsamında uygulanan analizler en az üç tekrarlı olarak gerçekleştirilmiş, verilerin ortalama değerleri ve standart sapmaları hesaplanmıştır. Tavuk nugget sIVı kaplama formülasyonlarında BKT kullanımının kalite parametrelerine etkilerinin incelenmesi amacıyla Tek Yönlü Varyans Analizi (One-way ANOVA) uygulanmıştır. Farklı deneme gruplarına ait ortalamalar arasında \%95 güven aralığında anlamlı farklılıkların tespiti için Duncan Çoklu Karşılaştırma Testi kullanılmıştır.

\section{Araştırma Bulguları ve Tartışma Kimyasal Kompozisyon ve Enerji}

Tavuk nugget örneklerinin kimyasal kompozisyonu Çizelge 2'de sunulmaktadır. Örneklerin nem miktarının \%59.80-63.38, protein miktarının \%22.19-24.14, yağ miktarının
\%5.84-6.88, karbonhidrat miktarının \%5.338.22 ve kül miktarının \%1.60-1.84 aralığında olduğu tespit edilmiştir. Örneklerin nem miktarları birbirine benzer olup, formülasyona ilave edilen BKT'nin kuru madde miktarını değiştirmediği, böylece buğday unu veya BKT kullanımının örneklerin derin yağda kızartılması boyunca nem miktarlarını benzer seviyelerde tuttuğu görülmektedir. Benzer olarak Gökçe ve ark. (2016), buğday, mısır, soya ve çavdar unları ile hazırlanan sıvı kaplamalar ile muamele edilen tavuk nuggetlarda nem miktarının kullanılan undan etkilenmediğini bulgulamıştır. Öztürk (2018) ise yulaf lifi ve yer elması tozu gibi lifli bileşenlerin tavuk nugget sıvı kaplama formülasyonlarında kullanımının kuru madde miktarını yükselterek nem miktarını düşürdüğünü bildirmiştir. Sıvı kaplama hamurlarına artan oranlarda BKT ilavesinin örneklerin protein miktarını önemli düzeyde yükselttiği tespit edilmiştir $(p<0.05) . \quad B u$ durumda tavuk nuggetlarda BKT kullanımının ürünün besleyici değeri üzerinde olumlu etki sağlama potansiyeli olduğu söylenebilir. Nem miktarlarına benzer olarak, örneklerin yağ miktarları arasında da önemli bir farklılık olmadığı gözlenmiştir. Tavuk nuggetlarda kızartma süresince kullanılan unların karakteristiklerine bağlı olarak farklı miktarda yağın absorbe edilmesi söz konusudur (Öztürk, 2018). Bu durumda mevcut çalışmada kullanılan BKT'nin buğday ununa benzer oranda yağ emilim düzeyine sahip olduğu ve böylece kızartma sonrası örneklerde tespit edilen yağ miktarlarının farklılık göstermediği düşünülmektedir. Bu durumun aksine, çeşitli çalışmalarda farklı diyet lifi içerikli bileşenler ile formüle edilen kaplamalı tavuk eti ürünlerinde yağ miktarının azaldığı bildirilmiştir (Kilincceker, 2013; Öztürk, 2018). BKT ile formüle edilen örneklerin inorganik madde kompozisyonunun değişimine bağlı olarak kül miktarının önemli düzeyde değiştiği tespit edilmiştir $(p<0.05)$. Deneme örneklerinin enerji değeri 168.11$188.25 \mathrm{kcal} / 100 \mathrm{~g}$ aralığında değişmiş ve enerji değerleri arasında anlamlı farklılık kaydedilmemiştir. Yağ ve karbonhidrat miktarlarının benzer olması nedeniyle örneklerin enerji değerleri arasında farklıık saptanmadığı görülmektedir. 
Çizelge 2. Tavuk nugget örneklerinin kimyasal kompozisyonu ve enerji değeri

\begin{tabular}{cccc}
\hline & \multicolumn{3}{c}{ Deneme grupları* } \\
\hline Nem (\%) & $\mathrm{K}$ & $\mathrm{BK}$ & $\mathrm{B}$ \\
\hline Protein (\%) & $63.38 \pm 2.30$ & $61.37 \pm 2.70$ & $59.80 \pm 2.46$ \\
\hline Yağ (\%) & $22.96^{\mathrm{ab} \pm 0.73}$ & $22.19^{\mathrm{b}} \pm 0.19$ & $24.14^{\mathrm{a} \pm 0.17}$ \\
\hline Karbonhidrat (\%) & $5.84 \pm 0.84$ & $6.43 \pm 1.04$ & $6.88 \pm 0.46$ \\
\hline Kül (\%) & $5.33 \pm 1.86$ & $8.22 \pm 1.79$ & $7.61 \pm 1.65$ \\
\hline Enerji (kcal/100 g) & $1.84^{\mathrm{a} \pm 0.07}$ & $1.79 \mathrm{~b} \pm 0.09$ & $1.60^{\mathrm{b}} \pm 0.02$ \\
\hline
\end{tabular}

* K: Un fazının tamamı buğday unu içeren sıvı kaplamalı deneme grubu, BK: Un fazında buğday unu ve bal kabağı tozu karışımı (1:1) içeren sıvı kaplamalı deneme grubu, B: Un fazının tamamı bal kabağı tozu içeren sıvı kaplamalı deneme grubu. Verilerin ortalama değerleri \pm standart sapma ile birlikte sunulmuştur. a, b, c, ...: Aynı satırdaki farklı harfler istatistiksel olarak anlamlı farklılığı göstermektedir $(p<0.05)$.

\section{Teknolojik Karakterler}

Tavuk nugget kaplama formülasyonlarında kullanılan sıvı kaplamaların konsistens değerleri, nugget örneklerinin kaplama tutunma oranı (KTO), pişirme verimi (PV) ve yağ emilim miktarı (YEM) Şekil 2'de sunulmaktadır. Kaplamalı tavuk eti ürünleri üretiminde tüm kaplama basamaklarında en yaygın olarak kullanılan bileşenlerin başında buğday unu ve türevleri gelmektedir. Sıvı kaplama hazırlamada buğday unu içeren kaplamalar, su ile kolay karışabilmekte ve çözelti içerisinde uzun süre askıda kalabilmektedir (Kaymak-Ertekin, 2005). Bu durumda sıvı kaplamaların akış özelliği, farklı bileşenlerin kullanımına bağı olarak değişebilmekte ve böylece ürün verimi etkilenebilmektedir. Sıvı kaplamalarda akışkanlığın bir ölçüsü olarak ifade edilen konsistens değerleri 10.78-11.17 cm aralığında değişmiştir. Kaplamaların konsistens değerleri arasında istatistiksel farklılık saptanmamıştır. $\mathrm{Bu}$ durumda, formülasyonunda BKT kullanılan sıvı kaplama hamurlarında akışkanlığa karşı gösterilen direncin standart örneklere benzer olduğu görülmektedir. Çalışmada kullanılan kaplama hamurları, buğday unu ve BKT'nin su kaldırma kuvvetlerinin farklı olduğu öngörülerek farklı miktarlarda su kullanılarak hazırlanmıştır. Deneme formülasyonlarında da görülebileceği üzere (Çizelge 1), lifli yapısından dolayı daha yüksek su kaldırma kuvvetine sahip olan BKT gruplarında ilave edilen su miktarı da daha fazla olmuştur. Böylece hazırlanan sıvı kaplamaların akışkanlığının birbirine eşdeğer olması sağlanmıştır. Bu nedenle hazırlanan sıvı kaplama formülasyonlarının akış karakterlerinin birbirine yakın olması beklenen bir sonuçtur. Kaplama hamurlarının eşdeğer akış karakterlerine sahip olması sonucunda bu değer sabit tutularak kaplama işlemi ve pişirme boyunca üründeki davranışlar incelenmiş ve böylece kaplama formülasyonlarının içerikleri kaynaklı farklılıklar tespit edilmiştir. Literatürde yer alan çalışmalar incelendiğinde, sıvı kaplama formülasyonlarında kullanılan bileşenlerin değiştirildiği, ancak ilave edilen su miktarının sabit tutulduğu durumlarda akış karakteristiklerinin de etkilendiği raporlanmıştır (Dogan ve ark., 2005; Adedeji ve Ngadi, 2011). 

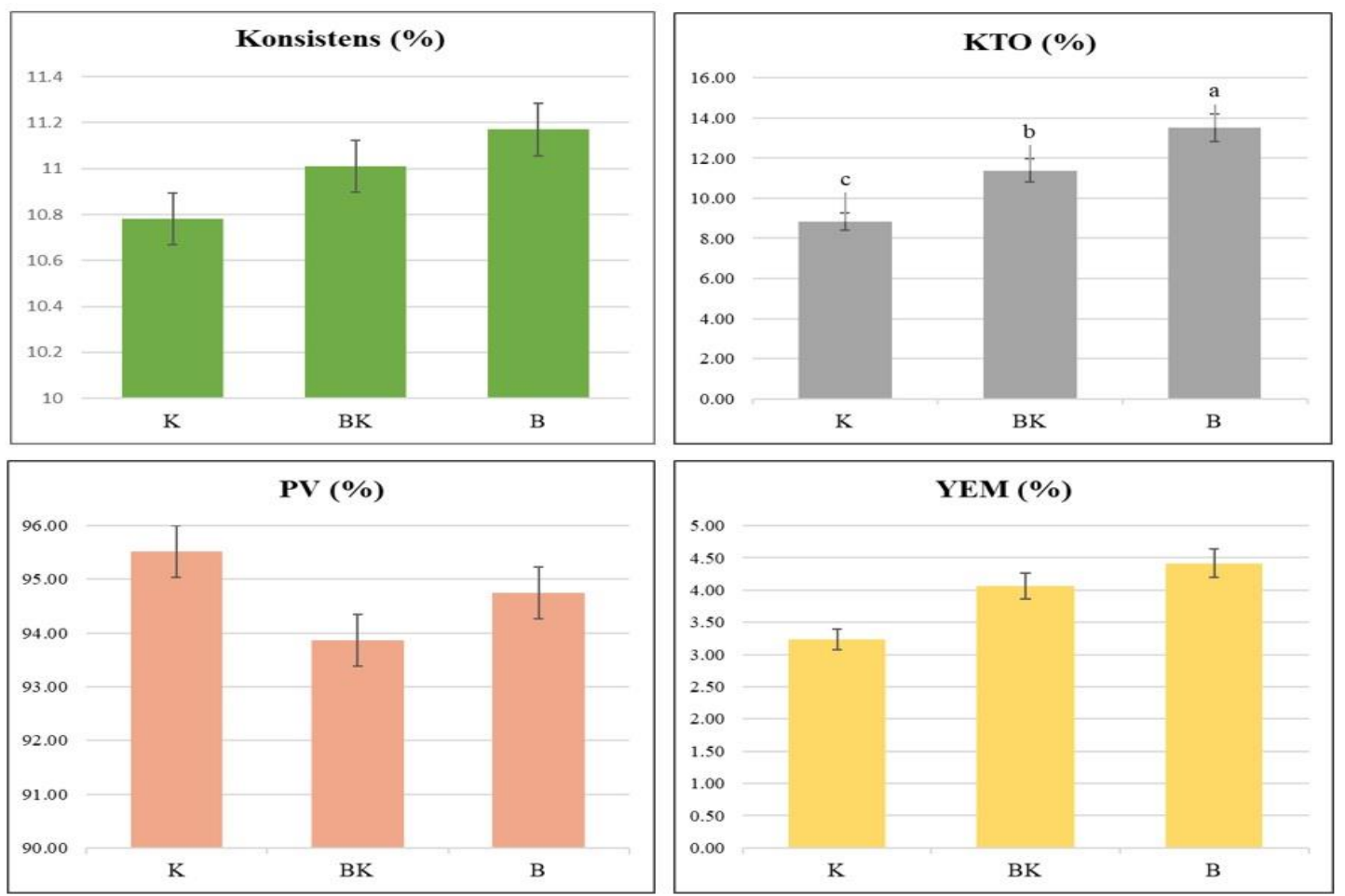

Şekil 2. Sıvı kaplama hamurlarının konsistens değerleri, tavuk nugget örneklerinin kaplama tutunma oranı (KTO), pişirme verimi (PV) ve yağ emilim miktarı (YEM). K: Un fazının tamamı buğday unu içeren sıvı kaplamalı deneme grubu, BK: Un fazında buğday unu ve bal kabağı tozu karışımı (1:1) içeren sıvı kaplamalı deneme grubu, B: Un fazının tamamı bal kabağı tozu içeren sıvı kaplamalı deneme grubu. a, b, c, ...: Farklı sütunlardaki farklı harfler istatistiksel olarak anlamlı farklılığı göstermektedir $(p<0.05)$.

Kaplamalı et ürünlerinde sıvı kaplamanın yüzeye tutunabilme derecesi, dış kaplama materyalinin tekdüze dağılımı etkileyen ve bu nedenle ürünün görünüm ve verimini belirleyen önemli bir ölçüttür (Öztürk, 2018). Deneme gruplarında KTO \%8.84-13.53 aralı̆ı̆nda değişmiştir. Sıvı kaplama formülasyonlarının değişimi, örneklerde KTO değerini önemli düzeyde etkilemiş olup, gruplar arasında en düşük KTO, buğday unu ile formüle edilen $K$ grubunda kaydedilmiştir $(p<0.05)$. Kaplama formülasyonlarında buğday unu yerine BKT kullanımının ve artan BKT oranının, KTO'yu önemli düzeyde yükselttiği tespit edilmiştir $(p<0.05)$. Formülasyona BKT eklenmesi ile karakteristik lifli yapının su içerisinde dağılması sonucunda arzu edilen gözenekli yapı ve jelleşmenin oluştuğu ve böylece ön unlama işlemi gerçekleştirilen nugget porsiyonunun yüzeyinde sıvı kaplamanın yüksek düzeyde tutunabildiği düşünülmektedir. Yapılan bir çalışmada, sıvı kaplamalarda lifli bileşenlerin kullanımının daha kararlı bir yapının oluşması ve kaplamanın ürün yüzeyinde daha kolay tutunmasını sağladığı bildirilmiştir (Öztürk,
2018). Bir diğer araştırmada, sıvı kaplama formülasyonlarında buğday, mısır, soya veya çavdar unu kullanılarak hazırlanan tavuk nuggetlarda en yüksek KTO çavdar unu içeren gruplarda kaydedilmiştir (Gökçe ve ark., 2016).

Kaplamalı et ürünleri üretiminde kullanılan kaplama materyallerinin tipi ve kimyasal kompozisyonları, ürünlerin derin yağda kızartılması esnasında su kaybı ve yağ emilim düzeyini etkilemektedir (Kilincceker, 2013). Deneme örneklerinde PV \%93.87-95.52 aralığında olup, değerler arasında anlamlı farklılık tespit edilmemiştir. Bu durumda sıvı kaplama içerisinde buğday unu yerine BKT kullanımı ve/veya BKT kullanım oranı, tavuk nuggetlarda pişirme boyunca yapıdan ayrılan sıvı miktarını değiştirmemiştir. BKT'nin içerisinde bulunan diyet liflerinin yüksek su tutma kapasitesi dolayısıyla ısıl işlem boyunca yapıda suyun arzu edilen oranda tutulabildiği ve buğday unu ile hazırlanan standart formülasyonlara eşdeğer verimin elde edildiği görülmektedir. Benzer olarak Öztürk (2018), sıvı kaplama formülasyonlarında yer elması tozu veya yulaf lifi kullanılan tavuk nuggetların 
pişirme karakteristikleri açısından buğday unu kullanılan tüm kontrol formülasyonlarını karşıladığını raporlamıştır. PV sonuçlarına benzer olarak, örneklerin YEM sonuçlarının da (\%3.23-4.41) birbirine benzer olduğu bulgulanmıştır. Buna göre, farklı sıvı kaplama formülasyonlarının kullanımı, nuggetlarda derin yağda kızartma işlemi boyunca yapı tarafından tutulan yağ miktarını etkilememiştir. Nitekim deneme örneklerinin toplam yağ miktarları da (Çizelge 2) birbirine yakın bulunmuştur.

\section{Renk}

Et ve et ürünlerde renk, tüketici beğenisini etkileyen en önemli görsel kalite unsurudur. Kaplamalı et ürünlerinde dış kaplama materyalinin oluşturduğu kabuk, ürünün kendine özgü yüzey rengini oluşturmaktadır. Nugget örneklerinin renk parametreleri Şekil 3'te verilmiştir. Örneklerin L* (aydınlık), a* (kırmızılık) ve b* (sarılık) değerlerinin sırasıyla 37.19-47.75, 9.34-10.92 ve 13.05-22.50 aralığında değiştiği kaydedilmiştir. Sıvı kaplama formülasyonlarında buğday unu yerine BKT kullanımı ve artan BKT konsantrasyonu, nugget örneklerinde aydınlık ve sarılık değerlerini önemli derecede düşürmüştür $(p<0.05)$. K ve $B$ gruplarının $a^{*}$ değerlerinin ise birbirine yakın olduğu bulunmuştur. Tüm örneklerde dış kuru kaplamada standart olarak galeta unu kullanılmasına rağmen ürün renginin değiştiği görülmektedir. Bu durumda sıvı kaplama formülasyonlarında kullanılan bileşenlerin son ürün rengini yüksek oranda etkilediği görülmektedir. Yapılan bir çalışmada, tavuk nuggetlarda sıvı kaplama hamurunda buğday unu yerine pirinç unu ve hidrokolloid kullanımı kırmızılık ve sarılık değerlerinin yükselmesine neden olmuştur (Adedeji ve Ngadi, 2011). Dogan ve ark. (2005), soya unu içeren sıvı kaplamalar ile üretilen tavuk nugget örneklerinde, pirinç unu ve mısır-buğday unları ile hazırlanan örneklere kıyasla aydınlığın azaldığını ve kırmızılığın arttığını, örneklerin sarılık değerlerinin ise değişmediğini tespit etmiştir. Bir diğer araştırmada, farklı unlar kullanılarak hazırlanan sıvı kaplamalar ile muamele edilen tavuk nuggetlarda en koyu renkli örneğin soya unu, en açık renkli örneğin ise buğday unu içeren denemelere ait olduğu, örneklerin kırmızılık değerleri arasında farklılık olmadığı, en yüksek sarılık değerinin ise mısır unu içeren örneklerde kaydedildiği bildirilmiştir (Gökçe ve ark., 2016). Öztürk (2018), yer elması tozu ile hazırlanan sıvı kaplamalar ile muamele edilen tavuk nuggetlarda aydınlık ve sarılık değerlerinin düşerek rengin koyulaştığını raporlamıştır. Çalışma bulgularına göre, kaplama formülasyonlarında kullanılan farklı bileşenlerin karakteristik renk özellikleri ve derin yağda kızartma işlemi sırasında katıldıkları reaksiyonlar sonucunda son ürün renginin etkilendiği düşünülmektedir. Enstrümantal olarak farklılık gösteren renk parametrelerinin duyusal kaliteye yansımalarının da incelenmesi ve ürün görselliğinin tüketici beğenisi açısından değerlendirilmesi de oldukça önemlidir.

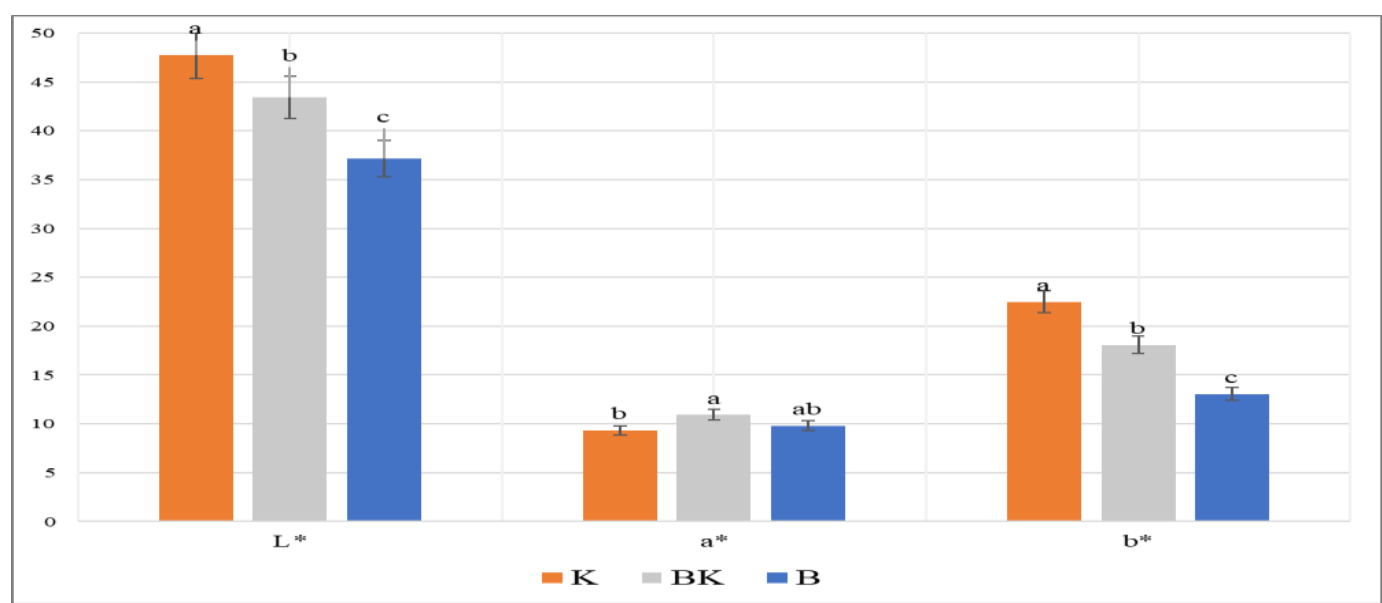

Şekil 3. Tavuk nugget örneklerinin renk $\left(L^{*}, a^{*}, b^{*}\right)$ değerleri K: Un fazının tamamı buğday unu içeren sıVı kaplamalı deneme grubu, BK: Un fazında buğday unu ve bal kabağı tozu karışımı (1:1) içeren sıvı kaplamalı deneme grubu, B: Un fazının tamamı bal kabağı tozu içeren sıvı kaplamalı deneme grubu. a, b, c, ...: Aynı parametrede bulunan farklı sütunlardaki farklı harfler istatistiksel olarak anlamlı farklılığı göstermektedir $(p<0.05)$. 


\section{Duyusal Değerlendirme}

Kaplamalı ürün formülasyonlarında kullanılan buğday ununun ana proteini olan gluten, kaplamada poroz yapının oluşması, üründe arzu edilen gevreklik ve kızarmış ürün renginin sağlanması üzerinde etkilidir (Akgün, 2006). Buğday unu alternatifi olarak kaplama bileşiminde kullanılacak girdilerin, ürünün sağlık profili ve teknolojik özelliklerini değiştirmelerinin yanı sıra duyusal karakterlerin değişimi üzerine olan etkilerinin de incelenmesi oldukça önemlidir. Taze veya kurutulmuş bal kabağının farklı et ürünleri formülasyonlarında kullanımını konu alan çalışmalarda, bal kabağının nötral aroması ve yoğun olmayan lezzetinden dolayı duyusal kalite üzerinde olumsuz etkilere yol açmadığı tespit edilmiştir (Ammar ve ark., 2014; Zargar ve ark., 2014; Serdaroğlu ve ark., 2018). Farklı oranlarda BKT kullanılarak üretilen tavuk nuggetların duyusal değerlendirme sonuçları Şekil 4'te sunulmaktadır. Örneklerin dış görünüş, renk, doku, çıtırlık, sululuk, yağlılık, lezzet ve genel kabul edilebilirlik puanlarının sırasıyla 6.2-7.5, 6.1-7.6, 6.7-7.2, 6.2-6.3, 6.7-7.1, 6.8-7.1, 7.0-7.1 ve 6.8-7.3 aralığında olduğu tespit edilmiştir. Değerlendirilen tüm kriterlere ait puanların kabul edilebilir sınırlarda olduğu görülmektedir. Buğday unu ile formüle edilen $\mathrm{K}$ örneklerinin dış görünüş ve renk puanlarının $B K$ ve $B$ örneklerinden daha yüksek olduğu tespit edilmiştir $(p<0.05)$. Bu durumda, enstrümantal renk parametrelerine benzer olarak, sıvı kaplamada farklı oranlarda BKT kullanımının, örneklerin dış kaplama materyali standart olmasına rağmen ürünün karakteristik renginin değişimine neden olduğu söylenebilir. Ancak BKT kullanımı, ürünün görsel kalite kriterlerinde farklılık yaratmasına rağmen diğer kalite kriterlerini olumsuz yönde etkilememiş ve örneklerin doku, çıtırlık ve lezzet gibi diğer skorları istatistiksel olarak birbirine benzer bulunmuştur. BKT ile formüle edilen örneklerin genel kabul edilebilirlik puanları da kullanılan BKT miktarından bağımsız olarak kontrol örneklerine yakındır. Bu nedenle sıvı kaplama formülasyonlarında BKT kullanılarak üretilen tavuk nuggetların genel duyusal kabulünün buğday unu kullanılarak üretilen örneklere eşdeğer olduğu görülmektedir. Zeng ve ark. (2016), farklı oranlarda bambu lifi ile hazırlanan sıvı kaplama formülasyonlarının balık nuggetlarda duyusal kaliteyi geliştirdiğini bildirmiştir. Benzer bir çalışmada, yer elması tozu ve yulaf unu gibi lifli bileşenlerin sıvı kaplama girdisi olarak kullanıldığ tavuk nuggetların duyusal parametre puanlarının kontrol gruplarına benzer olduğu bulgulanmıştır (Öztürk, 2018). Kwaw ve ark. (2017) tarafından gerçekleştirilen bir diğer çalışmada, eşit oranlarda soya ve sorgum unları ile kaplanarak kızartılan tavuk göğüs dilimlerinin duyusal kabul edilebilirliğinin buğday unu ile kaplananlara eşdeğer olduğu bildirilmiştir. Sonuç olarak, diyet lifi bakımından zengin bileşenlerin kaplamalı et ürünleri formülasyonlarında kullanımının ürünlerin genel duyusal kalitesini koruyucu bir etki sağladığı görülmektedir.

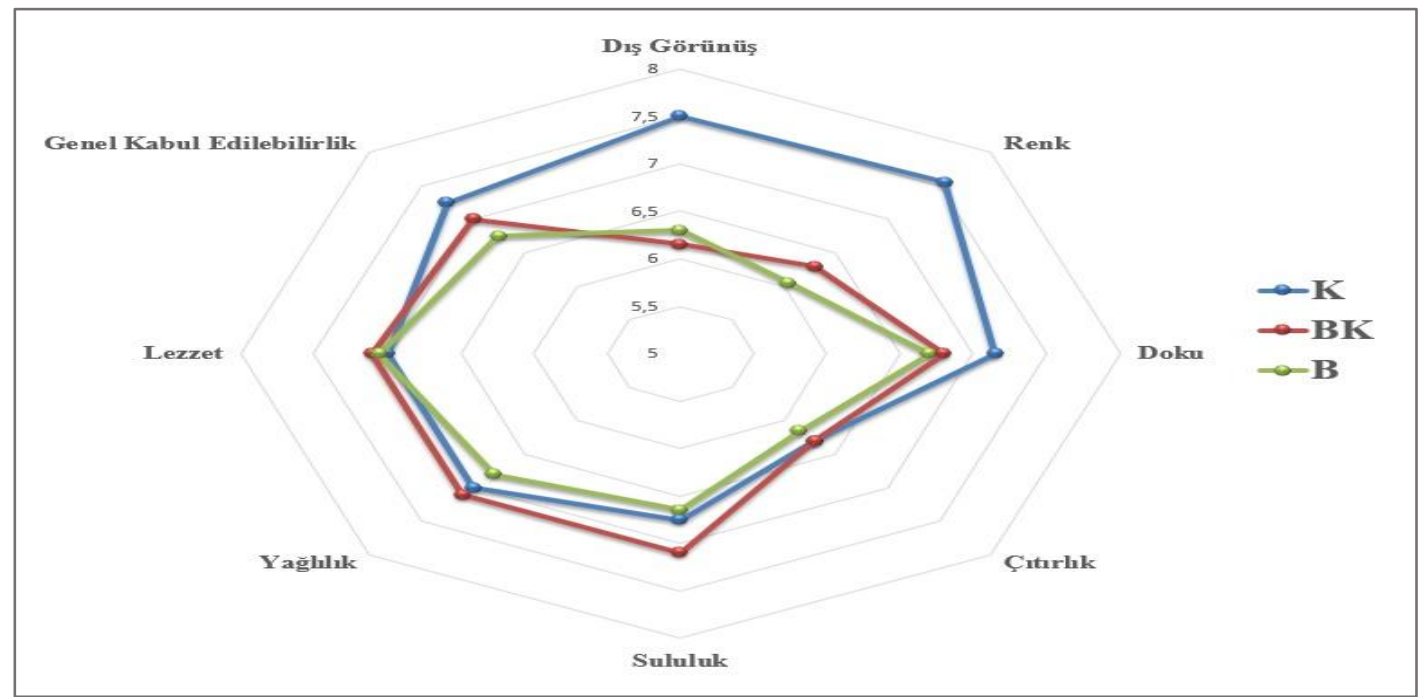

Şekil 4. Tavuk nugget örneklerinin duyusal değerlendirme puanları K: Un fazının tamamı buğday unu içeren sıvı kaplamalı deneme grubu, BK: Un fazında buğday unu ve bal kabağı tozu karışımı (1:1) içeren sıvı kaplamalı deneme grubu, B: Un fazının tamamı bal kabağı tozu içeren sıvı kaplamalı deneme grubu. 


\section{Sonuç ve Öneriler}

Mevcut çalışma bulguları, kaplamalı et ürünlerinde sıvı kaplama formülasyonlarında buğday unu yerine BKT kullanımının ürünün besleyici değerini yükselttiğini ve teknolojik kalitesini iyileştirdiğini göstermektedir. Diyet lifi açısından önemli bir kaynak olan BKT, sağlıklı et ürünleri formülasyonlarının geliştirilmesini sağlarken aynı zamanda su tutma özelliklerinin kuvvetli olmasından dolayı hazırlanan kaplamaların ürün yüzeyinde adsorbe olma yeteneğini yükseltmiştir. Ancak artan BKT oranlarının ürünlerde enstrümantal renk parametrelerini önemli düzeyde değiştirdiği görülmüştür. Duyusal kalite açısından irdelendiğinde ise, sıvı kaplamada BKT kullanımının ürünlerde görünüm ve renk beğenisini olumsuz yönde etkilediği, ancak diğer lezzet, doku ve genel kabul edilebilirliğin standart ürünlere eşdeğer olduğu belirlenmiştir. Bundan sonra yapılacak araştırmalarda, özellikle farklı dış kaplama materyallerinin kullanımı ile diyet liflerinin son üründe görsel kalite üzerinde neden olabileceği olası dezavantajların önlenmesi konusunun araştırılması önerilmektedir.

\section{Teşekkür}

Denemelerin yürütülmesi sırasında verdikleri destekten dolayı Ege Üniversitesi Gıda Mühendisliği Bölümü lisansüstü öğrencileri Hülya Serpil Kavuşan ve Gamze İpek ile lisans öğrencileri Melih Sarıcalı ve Dilara Kişi'ye teşekkür ederiz.

\section{Kaynaklar}

Adedeji, A.A., Ngadi, M.O. 2011. Microstructural properties of deep-fat fried chicken nuggets coated with different batter formulation. International Journal of Food Properties, 14(1): 68-83.

Akgün, A.A. 2006. Farklı Kaplama Formülasyonları ile Kaplanmış Tavuk Köftelerinin Duyusal, Fiziksel, Kimyasal ve Mikrobiyolojik Özellikleri. Pamukkale Üniversitesi, Fen Bilimleri Enstitüsü Yüksek Lisans Tezi, Denizli, $75 \mathrm{~s}$.

Ali, H.A., Mansour, E.H., E-IBedawey, A.E.F.A., Osheba, A.S. 2019. Evaluation of tilapia fish burgers as affected by different replacement levels of mashed pumpkin or mashed potato. Journal of the Saudi Society of Agricultural Sciences, 18(2):
127-132.

Ammar, A.S.M., El-Hady, E.S.A.A., El-Razik, M.M.A. 2014. Quality characteristics of low-fat meat balls as affected by date seed powder, wheat germ and pumpkin flour addition. Pakistan Journal of Food Sciences, 24: 175-185.

AOAC. 2012. Official Methods of Analysis. 19th ed. Association of Official Analytical Chemists, Gaithersburg, MD, USA.

Azevedo-Meleiro, C.H., Rodriguez-Amaya, D.B. 2007. Qualitative and quantitative differences in carotenoid composition among Cucurbita moschata, Cucurbita maxima, and Cucurbita pepo. Journal of Agricultural and Food Chemistry, 55(10): 4027-4033.

Babaoğlu, D., Türkmen, Ö. 2017. Batı Anadolu kaynaklı bal kabağı (Cucurbita moschata Duchesne) genotiplerinin bazı meyve özellikleri. Iğdır Üniversitesi Fen Bilimleri Enstitüsü Dergisi, 7(4): 11-16.

BESD-BiR. 2017. Beyaz Et Sanayicileri ve Damızlıkçıları Birliği Derneği "Istatistikler", http://www.besdbir.org/istatistikler (Erişim tarihi: 1 Ekim 2019).

Chen, S.D., Chen, H.H., Chao, Y.C., Lin, R.S. 2009. Effect of batter formula on qualities of deep-fat and microwave fried fish nuggets. Journal of Food Engineering, 95(2): 359-364.

Dar, A.H., Sofi, S., Rafiq, S. 2017. Pumpkin the functional and therapeutic ingredient: A review. International Journal of Food Science and Nutrition, 2(6): 165-170.

de Carvalho, L.R.S., da Silva, C.H., Giada, M.L.R. 2018. Physical, chemical and sensorial properties of low-fat and gluten-free chicken nuggets. Journal of Culinary Science and Technology, 16(1): 18-29.

Dogan, S.F., Sahin, S., Sumnu, G. 2005. Effects of soy and rice flour addition on batter rheology and quality of deep-fat fried chicken nuggets. Journal of Food Engineering, 71: 127-132.

Fedha, M.S. 2008. Physicochemical Characterization and Food Application Potential of Pumpkin (Cucurbita Sp.) Fruit and Seed Kernel Flours. Jomo Kenyatta University of Agriculture and Technology, Master's Thesis, Juja, $103 \mathrm{p}$.

Flynn, A.W., Bramblett, V.D. 1975. Effects of frozen storage, cooking method and muscle quality on attributes of pork loins. 
Journal of Food Science, 40(3): 631-633.

Gökçe, R., Akgün, A.A., Ergezer, H., Akcan, T. 2016. Farklı kaplama bileşenleriyle kaplamanın derin yağda kızartılan piliç nuggetların bazı kalite karakteristikleri üzerine etkileri. Tarım Bilimleri Dergisi, 22(3): 331-338.

Kaymak-Ertekin, F. 2005. Gıda maddelerinin kaplanması: Kaplama yöntem ve ekipmanlarl. Pamukkale Üniversitesi Mühendislik Bilimleri Dergisi, 11(1): 8594.

Kilincceker, O. 2013. Utilization of oat flour as edible coating material on fried chicken meat balls. Focusing on Modern Food Industry, 2(1): 36-42.

Kim, H.J., Paik, H.D. 2012. Functionality and application of dietary fiber in meat products. Korean Journal for Food Science of Animal Resources, 32(6): 695-705.

Kwaw, E., Sackey, A.S., Apaliya, M.T., Tchabo, W. 2017. Utilization of composite flours as breading agents for deep frying of chicken breast. Journal of Food Measurement and Characterization, 11(3): 1523-1530.

Mansour, E.H., Khalil, A.H. 1997. Characteristics of low-fat beefburger as influenced by various types of wheat fibers. Food Research International, 30: 199-205.

Murphy, E.W., Criner, P.E., Gray, B.C. 1975. Comparisons of methods for calculating retentions of nutrients in cooked foods. Journal of Agricultural and Food Chemistry, 23: 1153-1157.

Olmedilla-Alonso, B., Jiménez-Colmenero, F., Sanchez-Muniz, F.J. 2013. Development and assessment of healthy properties of meat and meat products designed as functional foods. Meat Science, 95(4): 919-930.

Öztürk, B. 2018. Kanatı Eti Ürünleri Üretiminde Yenilikçi Formülasyon Yaklaşımları: Farklı Teknolojilerle Üretilen Tavuk Eti Ürünlerinde Fosfat ve Gluten Alternatifi Bileşenlerin Kullanımının Araştırılması. Ege Üniversitesi Fen Bilimleri Enstitüsü Doktora Tezi, İzmir, $283 \mathrm{~s}$.
Öztürk, B., Serdaroğlu, M. 2017a. A rising star prebiotic dietary fiber: Inulin and recent applications in meat products. Journal of Food and Health Science, 3(1): 12-20.

Öztürk, B., Serdaroğlu, M. 2017b. Et ve et ürünlerinde fosfatlar: İşlevleri ve ikame olanaklarının güncel çerçevede değerlendirilmesi. Gıda, 42(5): 535-545.

Pathera, A.K., Riar, C.S., Yadav, S., Sharma, D.P., Yadav, Y.S., Kumar, M. 2017. Optimization of dietary fiber enriched chicken nuggets for different cooking methods. Journal of Food Measurement and Characterization, 11(3): 1386-1397.

Serdaroğlu, M., Kavuşan, H.S., İpek, G., Öztürk, B. 2018. Evaluation of the quality of beef patties formulated with dried pumpkin pulp and seed. Korean Journal for Food Science of Animal Resources, 38(1): 3-13.

Stone, H., \& Sidel, J.L. 2004. Sensory evaluation practices (3rd ed.). Elsevier Academic Press, UK.

TAGEM, 2018. T.C. Tarım ve Orman Bakanlığı, TAGEM Kanatlı Hayvancılık Sektör Politika Belgesi 2018-2022, Ankara. https://www.tarimorman.gov.tr/TAGEM/ Belgeler/yayin/Kanatl\%C4\%B1\%20Hayvan c\%C4\%B1I\%C4\%B1k\%20Sekt\%C3\%B6r\%2 OPolitika\%20Belgesi\%202018-2022.pdf (Erişim Tarihi: 01.09.2019).

WATT. (2018). WATT Executive Guide to World Poultry Trends 2018. http://www.poultrytrends.com/201811/ (Erişim Tarihi: 10.09.2019).

Zargar, F.A., Kumar, S., Bhat, Z.F., Kumar, P. 2014. Effect of pumpkin on the quality characteristics and storage quality of aerobically packaged chicken sausages. SpringerPlus, 3:39.

Zeng, H., Chen, J., Zhai, J., Wang, H., Xia, W., Xiong, Y.L. 2016. Reduction of the fat content of battered and breaded fish balls during deep-fat frying using fermented bamboo shoot dietary fiber. LWT - Food Science and Technology, 73: 425-431. 